\title{
Complicated or non-complicated appendicitis? That is the question
}

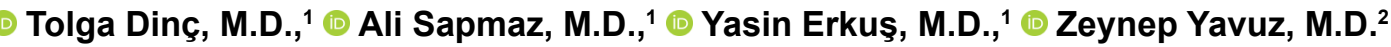

${ }^{1}$ Department of General Surgery, Ankara City Hospital, Ankara-Turkey

${ }^{2}$ Department of Biostatistics, Ankara University Faculty of Medicine, Ankara-Turkey

\begin{abstract}
BACKGROUND: Acute appendicitis (AA) is a common disease that includes all age groups and both genders in societies and is one of the most common causes of acute abdomen. It is important to distinguish between complicated and non-complicated appendicitis before surgery. This study aims to determine laboratory parameters that can be used to determine whether the disease is complicated or non-complicated in patients admitted to the emergency department with AA.

METHODS: Female and male patients admitted to the Emergency General Surgery Department between May 2019 and November 2020 and diagnosed with appendicitis were included in the study. Demographic data (age, gender, and protocol numbers), complete blood counts (Delta neutrophil index [DNI], hemoglobin, monocyte, neutrophil, eosinophil, basophil, platelet, platelet distribution width, mean platelet volume, reticulocyte distribution width), biochemical parameters (amylase, direct bilirubin, indirect bilirubin, albumin, calcium, and lactate dehydrogenase), and examination information were obtained from the hospital automation system and recorded via SPSS software. Parameters of patients were divided into two groups as complicated and non-complicated appendicitis groups were compared.
\end{abstract}

RESULTS: White blood cell (WBC), monocyte, neutrophil, DNI, total bilirubin, and direct bilirubin values were found to be statistically significantly higher in the complicated appendicitis group compared to the non-complicated appendicitis group ( $\mathrm{p}$-values; $<0.00 \mathrm{I}$, $0.003,<0.001,<0.001$ and 0.008 , respectively).

CONCLUSION: DNI, bilirubin values, WBC, monocyte, neutrophil, and eosinophil can be used as laboratory parameters to distinguish between complicated and non-complicated AA.

Keywords: Appendicitis; bilirubin; delta neutrophil index.

\section{INTRODUCTION}

Acute abdominal cases account for about 5-10\% of emergency admissions. ${ }^{[1]}$ Acute abdominal signs emerge at varying degrees, ranging from relatively moderate life-threatening cases to serious life-threatening cases. One of the causes of acute abdomen is acute appendicitis (AA). ${ }^{[2]} \mathrm{AA}$ is the most common disease leading to the acute abdomen in all age groups. ${ }^{[3,4]}$ Delays in diagnosis may cause complications in appendicitis. This may lead to serious morbidity and mortality. ${ }^{[5]}$ AA is grouped as complicated and non-complicated appendicitis. The presence of an abscess, phlegmon and perforation are called complicated appendicitis. $^{[6,7]}$ It is important to determine whether the patient has complicated appendicitis in planning the treatment of patients. The use of computed tomography in the evaluation of this condition is fairly common in the clinic. However, a practical laboratory test that can predict this situation continues to be sought considering the radiation the patient is exposed to and the loss of the radiologist's workforce.

This study aims to determine laboratory parameters that can be used to determine whether the disease is complicated or non-complicated in patients admitted to the emergency department with AA.

Cite this article as: Dinç T, Sapmaz A, Erkuş Y, Yavuz Z. Complicated or non-complicated appendicitis? That is the question. Ulus Travma Acil Cerrahi Derg 2022;28:390-394.

Address for correspondence: Tolga Dinç, M.D.

Ankara Şehir Hastanesi, Genel Cerrahi Kliniği, Ankara, Turkey

Tel: +90 312 - 5526000 E-mail: tolga_dr@hotmail.com

Ulus Travma Acil Cerrahi Derg 2022;28(3):390-394 DOI: 10.14744/tjtes.202I.56244 Submitted: 09.04.202I Accepted: 17.06.202I

Copyright 2022 Turkish Association of Trauma and Emergency Surgery 


\section{MATERIALS AND METHODS}

The research was planned as a retrospective clinical study. Ethics committee approval was obtained from the Local Ethics Committee for this study (E2-20-I0I). Female and male patients of all age groups admitted to the Emergency General Surgery Department between May 2019 and November 2020, diagnosed with appendicitis, operated, and diagnosed with appendicitis pathologically were included in the study. Demographic data (age, gender, and protocol numbers), complete blood counts (Delta neutrophil index [DNI], hemoglobin, monocyte, neutrophil, eosinophil, basophil, platelet, platelet distribution width, mean platelet volume, reticulocyte distribution width), biochemical parameters (amylase, direct bilirubin, indirect bilirubin, albumin, calcium, and lactate dehydrogenase), and examination information were obtained from the hospital automation system and recorded via SPSS software. The patients were divided into two groups as complicated and non-complicated appendicitis according to the histopathological examination reports. Perforated appendicitis, acute phlegmonous appendicitis, acute gangrenous appendicitis, and abscess were determined as complicated appendicitis whereas patients diagnosed with AA were classified as non-complicated appendicitis.

Patients who were operated on for appendicitis but developed inflammatory bowel diseases (ulcerative colitis and Crohn's disease) and malignancy on pathological examination were excluded from the study.

\section{Statistical Analysis}

Descriptive statistics are presented as frequency (percentage) for categorical and median (minimum-maximum) for numerical variables. The assumption of normality for numerical variables was assessed analytically with Kolmogorov-Smirnov Test and visually by graphical methods. Patient characteristics and preoperative laboratory data comparisons between non-compli- cated and complicated appendicitis groups were made with Chi-square test for categorical and Independent Samples t-test or Mann-Whitney $U$ test for numerical variables. Standardized effect sizes (Cohen's d) of group laboratory data differences were calculated using their corresponding $\mathrm{z}$ test statistic values. Diagnostic ability of the laboratory parameters that had a significant $\mathrm{p}$-value regarding their group comparison test results was evaluated using the area under the receiver operating characteristic Curve. Cut-off values for the potential markers were obtained using Youden's Index and diagnostic performance measures; sensitivity, specificity, and their corresponding $95 \%$ confidence intervals were calculated. Statistical analyses were performed using Statistical Package for Social Sciences (SPSS, SPSS Inc. Version II.5, Chicago, IL) software, and $p<0.05$ were considered statistically significant.

\section{RESULTS}

A total of 576 patients were included in the study. Of the patients, 342 were male $(59.4 \%)$ and $234(40.6 \%)$ were female. The mean age of the patients was $35.53 \pm 14.55$ (mean \pm SD). $382(66.3 \%)$ of the patients had non-complicated appendicitis and $194(33.7 \%)$ had complicated appendicitis. The distribution of the age, gender, type of surgery, and examination results of the patients according to the groups is shown in Table I. The distribution of all laboratory data of the patients is shown in Table 2. White blood cell (WBC), monocyte, neutrophil, DNI, total bilirubin, and direct bilirubin values were statistically significantly higher in the complicated group compared to the non-complicated group ( $\mathrm{p}$-values; $<0.00$ I, $0.003,<0.00 \mathrm{I},<0.00 \mathrm{I}$, and 0.008 respectively). The diagnostic ability, performance measures, and cut-off values for the laboratory parameters are shown in Table 3.

\section{DISCUSSION}

AA is a very common cause of acute abdomen in society. It is also an important disease group because it affects all age

Table I. Evaluation of the age, gender, type of surgery, and examination results of the patients between the groups

\begin{tabular}{lccc}
\hline & Non-Complicated & Complicated & p-value \\
\hline $\begin{array}{l}\text { Gender, } \mathrm{n}(\%) \\
\quad \text { Male }\end{array}$ & $220(57.5)$ & $122(62.9)$ & 0.225 \\
$\quad 162(42.5)$ & $72(37.1)$ & \\
$\quad$ Female & $32(18-87)$ & $32(18-82)$ & 0.620 \\
Age (year) & $70(18.4)$ & $32(16.5)$ & 0.568 \\
Surge abdomen, $\mathrm{n}(\%)$ & & & \\
$\quad$ Open & $310(81.6)$ & $164(84.5)$ & 0.377 \\
$\quad$ Laparoscopic & $70(18.4)$ & $30(115.5)$ & \\
Right lower quadrant pain, $\mathrm{n}(\%)$ & $366(96.3)$ & $174(89.7)$ & $<0.001$ \\
\hline
\end{tabular}

Values are presented as median (minimum-maximum) unless stated otherwise. $P<0.05$ is statistically significant. 
Table 2. Distribution of laboratory data of patients by groups

\begin{tabular}{|c|c|c|c|c|}
\hline Parameter (unit) & Non-Complicated & Complicated & Effect Size (Cohen's d) & p-value \\
\hline WBC $(\mu \mathrm{l} / \mathrm{ml})$ & $12.7(3.3-25.6)$ & $14.4(2.7-34.3)$ & 0.371 & $<0.001$ \\
\hline Hemoglobin $(g / L)$ & $14.3(8.6-18.0)$ & $14.3(9.5-17.6)$ & 0.083 & 0.321 \\
\hline Monocyte (\%) & $0.59(0.04-1.82)$ & $0.65(0.09-7.40)$ & 0.253 & 0.003 \\
\hline Neutrophil (\%) & $10.0(1.0-22.7)$ & $11.9(0.4-30.0)$ & 0.433 & $<0.001$ \\
\hline Eosinophil (\%) & $0.09(0.00-1.65)$ & $0.07(0.01-0.60)$ & 0.193 & 0.021 \\
\hline Basophil (\%) & $0.03(0.00-0.40)$ & $0.03(0.00-0.31)$ & 0.018 & 0.827 \\
\hline Platelet (x|0^9/L) & $254(47-585)$ & $246(75-636)$ & 0.056 & 0.506 \\
\hline PDW (\%) & $55.75(20.0-153.6)$ & $55.5(17.5-78.2)$ & 0.026 & 0.759 \\
\hline MPV (fL) & $7.8(5.6-13.5)$ & $7.95(5.8-78.0)$ & 0.144 & 0.086 \\
\hline RDW (\%) & $13.2(11.5-19.2)$ & $13.1(11.6-19.5)$ & 0.126 & 0.131 \\
\hline DNI & $0.10(0.06-21.00)$ & $0.50(0.01-23.10)$ & 0.301 & $<0.001$ \\
\hline Albumin $(g / L)$ & $46(16-53)$ & $46(37-189)$ & 0.004 & 0.957 \\
\hline LDH (U/L) & $193(108-503)$ & $194.5(93-536)$ & 0.078 & 0.355 \\
\hline Amilaz (U/L) & $56.0(7.7-184.0)$ & $52.0(1.1-534.0)$ & 0.166 & 0.051 \\
\hline Total bilirubin (mg/dL) & $0.70(0.05-3.90)$ & $0.90(0.30-3.80)$ & 0.343 & $<0.001$ \\
\hline Direct bilirubin (mg/dL) & $0.20(0.10-1.10)$ & $0.30(0.04-3.00)$ & 0.223 & 0.008 \\
\hline Calcium (mg/dL) & $9.3(6.6-27.0)$ & $9.2(8.0-10.6)$ & 0.135 & 0.109 \\
\hline RDW/Platelet & $0.05(0.02-0.29)$ & $0.05(0.02-0.2 I)$ & 0.033 & 0.695 \\
\hline PDW/Platelet & $0.22(0.06-1.69)$ & $0.22(0.70-1.04)$ & 0.023 & 0.779 \\
\hline
\end{tabular}

Values are presented as median (minimum-maximum). Effect size thresholds: 0.2 -Small, 0.5-Medium, 0.8-Large, I.3-Very Large. P<0.05 is statistically significant. WBC: White blood cells; PDW: Platelet distribution width; MPV: Mean platelet volume; RDW: Red cell distribution width; DNI: Delta neutrophil index; LDH: Lactate dehydrogenase.

Table 3. ROC analysis results of laboratory parameters

\begin{tabular}{lccccc}
\hline & AUC (95\% Cl) & p-value & Cut-off value & Sensitivity (95\% Cl) & Specificity (95\% Cl) \\
\hline WBC & $0.606(0.558-0.655)$ & $<0.001$ & $\geq 13.75$ & $0.59(0.52-0.66)$ & $0.59(0.54-0.64)$ \\
Monocyte & $0.577(0.527-0.626)$ & 0.003 & $\geq 0.565$ & $0.68(0.61-0.75)$ & $0.47(0.42-0.53)$ \\
Neutrophil & $0.624(0.577-0.672)$ & $<0.001$ & $\geq 9.35$ & $0.75(0.69-0.8 I)$ & $0.44(0.39-0.49)$ \\
Eosinophil & $0.559(0.509-0.609)$ & 0.022 & $\leq 0.085$ & $0.58(0.50-0.65)$ & $0.52(0.47-0.57)$ \\
DNI & $0.583(0.533-0.633)$ & 0.001 & $\geq 0.55$ & $0.49(0.42-0.56)$ & $0.69(0.64-0.73)$ \\
Total Bilirubin & $0.603(0.555-0.651)$ & $<0.001$ & $\geq 0.65$ & $0.76(0.69-0.82)$ & $0.41(0.36-0.46)$ \\
DirectBilirubin & $0.566(0.516-0.615)$ & 0.011 & $\geq 0.25$ & $0.52(0.45-0.60)$ & $0.57(0.52-0.62)$ \\
\hline
\end{tabular}

ROC: Receiver Operating Characteristic; AUC: Area under curve; Cl: Confidence interval; WBC: White blood cells; DNI: Delta neutrophil index. P<0.05 is statistically significant.

and gender groups. ${ }^{[3,4]}$ Delays in diagnosis may result in complications. Clinical conditions such as abscess, gangrenous appendicitis, perforation, and phlegmon are called complicated appendicitis. It is also important to distinguish whether appendicitis is complicated in terms of arranging treatment, predicting what the surgeon will encounter in the surgery, and informing the patient. Clinicians can easily diagnose appendicitis. AA is the first disease that comes to mind in the emergency department, especially in patients with right lower quadrant pain. However, appendicitis is sometimes observed with unusual clinical signs. The patient's examination may not be interpreted as compatible with AA in this case. Meanwhile, right lower quadrant results may not be present in AA patient groups where complications such as perforation occur. The interpretation of other laboratory parameters becomes more important in this case. Moreover, right lower quadrant pain is less common in the complicated appendicitis group in our study. The importance of carefully examining and interpreting laboratory data once again emerges considering that routine computed tomography is a serious burden in terms of 
both burden on the healthcare system and patients' exposure to radiation. Length of hospital stay, rate of drain use, duration of antibiotic use also increases in cases with complicated appendicitis. The patient is prepared for a difficult treatment process both clinically and morally with prior knowledge of the complicated condition.

It is not surprising that the known acute inflammatory cells are significantly higher in the differentiation of complicated and non-complicated appendicitis, consistent with the literature. ${ }^{[8]}$ However, it is valuable to find $\mathrm{DNI}$ and bilirubin values as parameters that can be used to differentiate between complicated and non-complicated appendicitis.

Aydin et al. ${ }^{[8]}$ found that WBC above $13.8 \mu \mathrm{l} / \mathrm{ml}$ was significant in terms of complicated appendicitis diagnosis. Similarly, we found that WBC above $13.75 \mu \mathrm{l} / \mathrm{ml}$ might be an indicator of complication. DNI is a fraction of circulating immature granulocytes. There are studies showing that it is a useful marker of infection or inflammation. ${ }^{[9,10]}$ It is routinely evaluated in complete blood counts. There are also studies in the clinic showing that it is useful in predicting mortality in sepsis, disseminated intravascular coagulopathy, and bacteriemia. $[11,12]$ There are studies that DNI is a predictive marker that can be used to differentiate the perforated appendix from the non-perforated appendix in adults, ${ }^{[13]}$ elderly, ${ }^{[14]}$ and children. ${ }^{[15]}$ It was found that a DNI value $>0.6 \%$ was associated with complicated appendicitis in the study conducted by Shin et al. ${ }^{[13]}$ The cut-off value of above $0.55 \%$ for DNI may be significant in the differentiation of complicated and non-complicated appendicitis similar to the literature even though the discriminative ability was found to be poor.

Some studies have shown a relationship between perforated appendicitis and high bilirubin levels. ${ }^{[16,17]}$ Sand et al. ${ }^{[18]}$ found the specificity of high bilirubin levels in perforated appendicitis as $\mathbf{8 6 \%}$ in their study with 538 patients. The results of the study conducted by Kaser et al. ${ }^{[19]}$ were found to be parallel to the study conducted by Sand et al. ${ }^{[18]}$ Lin et al. ${ }^{[20]}$ showed that bilirubin had an anti-inflammatory effect and reduced peritonitis. This situation can be considered an anti-inflammatory defense mechanism of the body against inflammation in appendicitis. The cut-off value above 0.65 for total bilirubin was found to be rather sensitive in detecting complicated appendicitis in our study.

Studies using the medical treatment in appendicitis have been published recently. ${ }^{[21,22]}$ Treatments based on antibiotics are administered especially in non-complicated appendicitis. We believe that the use of other imaging tests and laboratory tests to make this distinction in appendicitis will be more effective in determining the severity of appendicitis.

The retrospective design of our study is the most important limitation. Another limitation is that routine parameters are requested as the only value when patients are admitted to the emergency department. Acute phase reactants such as ESR and CRP are not routinely requested and cannot be compared.

\section{Conclusion}

DNI, bilirubin values, WBC, monocyte, neutrophil, and eosinophil can be used as laboratory parameters to distinguish between complicated and non-complicated AA. There is a need for prospectively designed studies involving a large patient population.

Ethics Committee Approval: This study was approved by the Ankara City Hospital Clinical Research Ethics Committee (Date: 30.12.2020, Decision No: E2-20-101).

Peer-review: Internally peer-reviewed.

Authorship Contributions: Concept: T.D., A.S.; Design: T.D., Y.E.; Supervision: T.D., A.S.; Resource: T.D., Z.Y.; Materials: T.D., A.S., Y.E.; Data: Z.Y., Y.E.; Analysis: Z.Y., T.D.; Literature search: T.D., A.S., Z.Y., Y.E.; Writing: T.D., A.S., Z.Y., Y.E; Critical revision: T.D., A.S., Z.Y., Y.E.

Conflict of Interest: None declared.

Financial Disclosure: The authors declared that this study has received no financial support.

\section{REFERENCES}

1. Pitts SR, Niska RW, Xu J, Burt CW. National hospital ambulatory medical care survey: 2006 emergency department summary. Natl Health Stat Rep 2008;7:1-38.

2. Khanapure S, Nagral S, Nanavati AJ. A study of events between the onset of symptoms and hospital admission in patients with acute abdomen. Natl Med J India 2017;30:65-8.

3. Ozguner IF, Buyukayavuz BI, Savas MC. The influence of delay on perforation in childhood appendicitis. A retrospective analysis of 58 cases. Saudi Med J 2004;25:1232-6.

4. Zhang Y, Zhao YY, Qiao J, Ye RH. Diagnosis of appendicitis during pregnancy and peritoneal outcome in the late pregnancy. Chin Med 2009;122:521-4.

5. Vaziri M, Pazouki A, Tamannaie Z, Maghsoudloo F, Pishgahroudsari $\mathrm{M}$, Chaichian S. Comparison of pre-operative bilirubin level in simple appendicitis and perforated appendicitis. Med J Islam Repub Iran 2013;27:109-12.

6. Andersson RE, Petzold MG. Nonsurgical treatment of appendiceal abscess or phlegmon: A systematic review and meta-analysis. Ann Surg 2007;246:741-8. [CrossRef ]

7. Simillis C, Symeonides P, Shorthouse AJ, Tekkis PP. A meta-analysis comparing conservative treatment versus acute appendectomy for complicated appendicitis (abscess or phlegmon). Surgery 2010;147:818-29.

8. Aydin OU, Soylu L, Dandin O, Aydin EU, Karademir S. Laboratory in complicated appendicitis prediction and predictive value of monitoring. Bratisl Lek Listy 2016;117:697-701. [CrossRef ]

9. Kratz A, Maloum K, O’Malley C, Zini G, Rocco V, Zelmanovic D, et al. Enumeration of nucleated red blood cells with the ADVIA 2120 hematology system: An international multicenter clinical trial. Lab Hematol 2006;12:63-70. [CrossRef]

10. Nahm CH, Choi JW, Lee J. Delta neutrophil index in automated im- 
mature granulocyte counts for assessing disease severity of patients with sepsis. Ann Clin Lab Sci 2008;38:241-6.

11. Hwang YJ, Chung SP, Park YS, Chung HS, Lee HS, Park JW, et al. Newly designed delta neutrophil index-to-serum albumin ratio prognosis of early mortality in severe sepsis. Am J Emerg Med 2015;33:1577-82.

12. Kim HW, Ku S, Jeong SJ, Jin JS, Han SH, Choi JY, et al. Delta neutrophil index: Could it predict mortality in patients with bacteremia? Scand J Infect Dis 2012;44:475-80. [CrossRef]

13. Shin DH, Cho YS, Cho GC, Ahn HC, Park SM, Lim SW, et al. Delta neutrophil index as an early predictor of acute appendicitis and acute complicated appendicitis in adults. World J Emerg Surg 2017;12:32.

14. Shin DH, Cho YS, Kim YS, Ahn HC, Oh YT, Park SO, et al. Delta neutrophil index: A reliable marker to differentiate perforated appendicitis from nonperforated appendicitis in the elderly. J Clin Lab Anal 2018;32:e22177. [CrossRef]

15. Kim OH, Cha YS, Hwang SO, Jang JY, Choi EH, Kim HI, et al. The use of delta neutrophil index and myeloperoxidase index for predicting acute complicated appendicitis in children. PLoS One 2016;1:e0148799. [CrossRef ]

16. Ortega-Deballon P, de Adana-Belbel JC, Hernandez-Matias A, Garcia-Septiem J, Moreno-Azcoita M. Usefulness of laboratory data in the management of right iliac fossa pain in adults. Dis Colon Rectum 2008;51:1093-9. [CrossRef ]

17. Gronroos JM, Gronroos P. Leucocyte count and C-reactive protein in the diagnosis of acute appendicitis. Br J Surg 1999;86:501-4. [CrossRef ]

18. Sand M, Bechara FG, Holland-Letz T, Sand D, Mehnert G, Mann B. Diagnostic value of hyperbilirubinemia as a predictive factor for appendiceal perforation in acute appendicitis. Am J Surg 2009;198:193-8. [CrossRef ]

19. Kaser SA, Frankhauser G, Willi N, Mauer CA. C reactive protein is superior to bilirubin for anticipation of perforation in acute appendicitis. Scand J Gastroenterol 2010;45:885-92. [CrossRef ]

20. Lin Y, Wang S, Yang Z, Gao L, Zhou Z, Yu P, et al. Bilirubin alleviates alum-induced peritonitis through inactivation of NLRP3 inflammasome. Biomed Pharmacother 2019;116:108973. [CrossRef ]

21. Coccolini F, Fugazzola P, Sartelli M, Cicuttin E, Sibilla MG, Leandro $\mathrm{G}$ et al. Conservative treatment of acute appendicitis. Acta Biomed 2018;89:119-34.

22. Varadhan KK, Neal KR, Lobo DN. Safety and efficacy of antibiotics compared with appendicectomy for treatment of uncomplicated acute appendicitis: A meta-analysis of randomized controlled trials. BMJ 2012;344:e2156. [CrossRef]

\section{ORIJINAL ÇALIŞMA - ÖZ}

\section{Komplike veya non-komplike apandisit? İşte bütün mesele bu Dr. Tolga Dinç, ${ }^{1}$ Dr. Ali Sapmaz, ${ }^{1}$ Dr. Yasin Erkuş, ${ }^{1}$ Dr. Zeynep Yavuz ${ }^{2}$}

${ }^{1}$ Ankara Şehir Hastanesi, Genel Cerrahi Kliniği, Ankara

${ }^{2}$ Ankara Üniversitesi Tıp Fakültesi, Biyoistatistik Anabilim Dalı, Ankara

AMAÇ: Akut apandisitler her yaş grubunu ve her iki cinsiyeti de içerisine alan toplumda yaygın görülen bir hastalık olup akut batının en sık sebeplerinden biridir. Komplike ve non-komplike ayrımının ameliyat öncesinde yapılması önemlidir. Çalışmanın amacı, acil servise akut apandisit ile gelen hastalarda, hastalığının komplike veya non-komplike olduğunu belirlemede kullanılabilecek laboratuvar parametrelerinin saptanmasıdır.

GEREÇ VE YÖNTEM: Çalışmaya, Mayıs 2019-Kasım 2020 tarihleri arasında, acil genel cerrahi servisine başvurmuş, apandisit tanısı konulmuş, kadın ve erkek hastalar alındı. Hastalara ait demografik veriler (yaş, cinsiyet, protokol numaraları), tam kan sayımları (DNI [Delta nötrofil indeks], hemoglobin, monosit, nötrofil, eozinofil, bazofil, trombosit, platelet distribution width [PDW], mean platelet volume [MPV], reticulocyte distribution width [RDW]), biyokimyasal parametreleri [amilaz, direk bilirubin, indirek bilirubin, albumin, kalsiyum], laktat dehidrogenaz [LDH]), muayene muayene bilgileri hastane otomasyon sisteminden elde edilip SPSS programı ile kayıt altına alındı. Komplike ve non-komplike olarak iki gruba ayrılan hastaların parametreleri karşılaştıııldı.

BULGULAR: Komplike ve nonkomplike hasta grupları karşılaştırıldığında; beyaz küre, monosit, nötrofil, DNI, total bilirubin ve direkt bilirubin değerleri açısından istatistiki fark saptanmıştır ( $p$ değerleri sırası ile; $<0.00$ I, $0.003,<0.00$ I, $<0.00$ Ive 0.008 'dir).

TARTIŞMA: Akut apandisitte, komplike ve non-komplike ayrımını yapmada, laboratuvar parametreleri olarak WBC, monosit, nötrofil, eozinofil, DNI, bilirubin değerleri kullanılabilir.

Anahtar sözcükler: Apandisit; bilirubin; delta neutrophil indeks.

Ulus Travma Acil Cerrahi Derg 2022;28(3):390-394 doi: 10.14744/tjtes.2021.56244 